\title{
The Effect Of Government Support, Participation Of Members, Manager's Performance, And Access To Capital Sources On The Performance Of Cooperatives, Economy And Welvare of The Members In The City Of Tourist Batu East Java Indonesia.
}

\author{
MK. Burhanul Arifin \\ Doktoral Student of Economics, \\ University of 17 Agustus 1945 Surabaya \\ Ujianto \\ University of 17 Agustus 1945 Surabaya \\ Slamet Riyadi \\ University of 17 Agustus 1945 Surabaya
}

\begin{abstract}
An interesting thing of Batu City is the acceleration of its growth, which, during the last 12 years, has become the third most visited city by Asian tourists, after Bali and the Special Region of Yogyakarta. Batu City has a special character that is different from other cities, namely the beautiful atmosphere of the mountains, the cool air, lush with fruits, vegetables, flowers, and agricultural and livestock products. Starting from 6 tourist attractions now it has had more than $\mathbf{4 0}$ tourist destinations so that it becomes very popular. However, the growth of Batu City has not been accompanied by the economic growth of its people, resulting in a gab between what is expected and what is real. The purpose of this research is to analyze, test, prove and evaluate the influence of independent variables of Government Support, Member Participation, Manager Performance, and Access to Capital Resources on the dependent variables namely Cooperative Performance, Member Economy and Member Welfare. The knowledge of the influence of the tested variables on the progress of cooperatives is helpful for evaluating the performance of cooperatives in order to improve the economy and the welfare of cooperative members in general. This research is an explanatory study through hypothesis testing. By using 2 versions of the statistical analysis, namely Regression Analysis and Structural Equation Modeling (SEM). SEM is needed to find out more in detail about the various factors / variables and find the most dominating indicators of the progress of the cooperative.The results of the analysis based on the Regression Test state that all 6 variables under study have a significant effect; moreover, Partial/Equivalent Tests find similar results. Furthermore, the Structural Modeling Test indicated that the 7 variables being studied were good. The hypothesis testing using Weigh Regression proves that the 7 hypotheses proved to be significantly influential. The Loading Factor analyses showed a significant effects of: 1) Government Support (Variable D) with a significance value of $0.034(p<0.05)$; 2) Member Participation (Variable A) with a significance value of $0.049(p<0.05)$; 3) Manager Performance (Variable M) with a significance value of $0.046(p<0.05)$; 4) Capital Access (Variable U) with a significance value of $0.036(p<0.05)$; 5) Cooperative Performance (Variable K) with a significance value of $0.028(p<0.05)$; 6 ) Member Economy (Variable EA) with a significance value of $0.028(p<0.05)$; 7) and Member Welfare (Variable P) with a significance value of $0,000(p<0.05)$. Thus, all of the seven proposed hypotheses proved to be confirmed. It implies that those seven variables significantly influence the progress of cooperatives; therefore, they can be used to study, analyze, evaluate and innovate the development of cooperatives in Batu Tourism City. If the cooperative is strong, the economy and the welfare of the members will automatically increase.
\end{abstract}

Keywords : cooperative, economy, welfare 


\section{INTRODUCTION}

Batu is a City of Tourism that is very fast development, within a period of 12 years has become the third largest tourist city visited by Asian tourists, after Bali, Yogyakarta / Yogyakarta and Batu City. However, the rapid growth of the tourist city is not considered able to encourage economic progress of the community as a whole. The Objective Conditions of the Cooperative Movement in Batu Tourism City are almost 190 cooperatives, but unfortunately only 62 cooperatives are included in the category of healthy cooperatives. namely: 1) The rapid development of the city has not been matched by the economic development of its people; 2) there is still a geb between the expectation that the community in cooperatives can improve the quality of life with the running reality; 3) the condition of community cooperatives is only $33 \%$ which is included in the category of healthy cooperatives.

Therefore it is necessary to optimize the coaching of cooperatives deemed necessary research to examine with certainty the factors / variables that influence the progress of cooperatives and the economic community. Therefore this research was carried out thanks to a concession with the Batu City Government to find the factors / variables that influence in developing and fostering cooperatives, as well as analyzing and evaluating in order to provide input / research reports, to draw up a design for coaching a cooperative movement in Batu Tourism City while helping the government in raising and improving the economy and welfare of the general public.

\section{LITERATUR REVEW AND HYPOTHESIS}

Cooperatives, both as a people's economic movement and as a business entity, have a role to play in creating a developed, just and prosperous society based on the Pancasila and the 1945 Constitution in the national economic system that is organized as a joint effort based on the principles of family and economic democracy. Therefore cooperatives need to build themselves up more and be built to be strong and independent based on the principles of cooperatives so that they can play a role as the pillars of the national economy, and that the development of cooperatives is the duty and responsibility of the government and all the people (Law 25/1992)

Cooperative as a business legal entity, requires a strategic management / management in order to achieve its goals well, to maximize provit. So cooperatives are often referred to as 'democratic' and 'participatory' organizations. Therefore, in developing cooperatives, it is necessary to examine the relationship between several factors / variables that influence the progress of cooperatives :

\section{Influence / relationship of Government Support Variables with Cooperative Performance:}

Definition of government support. Government support can be in the form of provision of regulations, laws, government regulations, mints, regional regulations, operational and technical guidelines, as well as periodic coaching conducted by the government to the cooperative movement, especially its management in order to understand and be able to manage cooperatives well. (Pratiwi K, 2010). According to Law No.25 of 1992, Government support can be in the form of fostering, creating and developing climates and conditions that encourage the growth and correcting of cooperatives: The Government provides guidance, facilities, and protection to cooperatives :

a. provide the widest possible business opportunity to the Cooperative; 
b. improve and strengthen the ability of cooperatives to become healthy, strong and independent cooperatives;

c. striving for a mutually beneficial business relationship between the Cooperative and other business entities;

d. to cultivate cooperatives in the community.

Article 62 states: In order to provide guidance and facilities to the Cooperative, the Government shall:

a. guiding Cooperative business in accordance with the economic interests of its members;

b. encourage, develop and assist the implementation of education, training, counseling, and cooperative research;

c. provide facilities to strengthen cooperative capital and develop cooperative financial institutions;

d. assist the development of cooperative business networks and mutually beneficial cooperation between cooperatives;

e. provide consulting assistance to solve problems that are aced by Cooperatives while still paying attention to the Articles of Association and Cooperative principles.

Aside from that, it also supports capital strengthening, in the form of grants, soft loans, and ordinary loans with recommendations to designated banks. Also in the form of production centers and market centers that accommodate the production results to be made sales centers, so as to facilitate the results process for Cooperatives and SMEs.

(Pratiwi K, 2010)

\section{Influence of Cooperative Member Participation variables with manager's performance.} According to Yunus Setiawan (2013) Understanding the participation of cooperative members means that members have a mental and emotional involvement in cooperatives directly, have the motivation to contribute to cooperatives, and various responsibilities for the achievement of organizational goals and cooperative efforts. Member participation in cooperatives can be formulated as the active and comprehensive involvement of members in decision making, policy making, business direction and steps, supervision of the course of cooperative efforts, participation of venture capital, in business utilization, as well as in enjoying the remaining business results. Member participation can also be interpreted as the participation of members in various forms of activities organized by the cooperative, both the position of the member as the owner and as the user / customer. The participation of these members is manifested in the form of an opinion and thoughts in making decisions, in supervision, attendance and activeness in member meetings, financial capital contributions, and utilization of services provided by cooperatives. Member participation is the key to the success of a cooperative organization and business. Literally, participation means increasing the participation of people who have the same vision and mission to develop the organization or cooperative business. That members guarantee honesty, loyalty, smart accuracy, fair participation, discipline and firmness to the agreement, termination code to stimulate mutual benefits, and transparency. The seven virtues are referred to as Social Capital. Things that can be categorized as social capital, including: 1) The truth to move trust. 2) Justice in a joint effort. 3) Goodness and honesty that always achieve improvement. 4). Responsibility in individuality and solidarity. 5). Healthy and intelligent and decisive understanding. 6). Help yourself and others. 7). Fulfillment of all life priorities priorities through cooperatives.

Members are the main factors that are very influential in cooperatives. Arifin (2006), because the cooperative was founded by Members. Members are the owners and at the same time users and customers of the cooperative. Members are the main factor of a cooperative, because 
Members should carry out their responsibilities, as owners, customers actively, and involve themselves in all activities carried out by cooperatives. Members are the main factors of a cooperative at least have 6 important functions in cooperatives: 1) Members as both owner and customer/user. 2) Members as sources of capital (principal, mandatory and voluntary savings capital). 3) Members as manager / management/supervisor. 4) Members as the highest authority/ important decision maker in the Member Meeting. 5) Members as bodyguards / controllers of cooperatives. 6) Members as supervisors even as risk bearers. (Arifin, 2008).

From the explanation above it can be said that Members are an important element for a cooperative's progress. Noor Akhlan (2008) states: "The ups and downs of cooperatives are in the hands of administrators" and "Forward and withdrawals of cooperatives are in the hands of Members". The development and development of a cooperative depends on the synergy between the management / management and the Members to take advantage of the opportunities that are around them. (Noor Akhlan, 2008). Profile of Member Participation in Cooperatives in East Java the tendency is already active. However, the level of participation of its members is still varied, as indicated by the presence of cooperatives with less active members' level of participation. The occurrence of this difference is in accordance with the opinion of Ropke (2003: 53) that the level of participation is determined by the characteristics of members, management and programs implemented by cooperatives.

According to Ropke (2003: 41) that member participation is needed to reduce the poor performance of cooperatives, prevent irregularities and make management or management more responsible.

Members / Workers are one of the important factors in the success of a cooperative. Implementing work must be based on the work discipline that has been established by the cooperative, to achieve the desired goals. Interaction through harmonious communication between management and members is very important to ensure the glory of an organization. (Handoko TH, 2001).

\section{Effect of manager performance variables with Cooperative Performance.}

Profile of Manager's Entrepreneurship Attitudes, Member Participation, Implementation of Development Strategies and Cooperative Business Performance have an influential relationship. Profile of Entrepreneurial Managers Entrepreneurial attitudes of managers in cooperatives already have a positive tendency. However, the attitude of the entrepreneur is still varied, this is indicated by the presence of a neutral managerial entrepreneurial attitude. The occurrence of differences in attitudes to the Manager is in accordance with the opinion of Bilson Simamora (2004: 180) that a person's attitude can be different from others, this is because the level of needs of each manager is different, perceptions of the reality faced are based on each other's perceptions and there are differences in processing their firsthand experience. The manager's entrepreneurial attitude with a positive tendency is the basis for managers to manage their businesses. In accordance with Mueller's opinion (1996: 9), that a person's positive attitude, it is possible to express the values that he believes, meaning that everyone will try to translate the values that he believes into the context of a more tangible attitude. Furthermore Mueller (1996: 7) states that the attitude that is followed by a belief there is a tendency that people will like and tend to have positive beliefs about the task and will realize their tendencies or desires into positive behavior. 
Profile of Cooperative Business Performance in East Java has a good tendency, but if viewed per cooperative the business performance is still varied, this is indicated by the cooperative business performance that is still lacking. The variation in business performance is due to differences in the ability of cooperatives in tartib to produce good business performance. In accordance with the opinion of Robbins (2001: 187) that performance is a function of ability, motivation, and opportunity. Physiologically, ability (ability), employees consist of potential ability (IQ) and reality ability (job knowledge and skills), meaning that employees who have IQs above average with adequate education for positions and skills in their daily work then he will more easily achieve the expected performance. So the manager's education level will affect his managerial ability.

Furthermore Lukman M. Baga (2003: 13) states that the role of a cooperative entrepreneur is different from entrepreneurship in general. Entrepreneurial managers of cooperatives do not work alone, but together with their members. Therefore, an entrepreneur manager is a leader. Leaders who are followed by their members, and also who develop the resources owned by their members, including members' human resources to develop and utilize available market opportunities. Partially, the manager's entrepreneurial attitude had a positive and significant effect on the implementation of the performance strategy of 0.37 .48 . This situation indicates that the implementation of marketing strategies $\mathbf{3 7 . 4 8} \%$ is determined by the entrepreneurial attitude of the manager. This proves that the manager's entrepreneurial attitude variable is an important factor that can predict the implementation of a success strategy. This finding is in accordance with the opinion of Bayu Krisnamurthi (2002: 6) that the entrepreneurial spirit of the cooperative reflects the soul of the superior (superior) officer who is not only innovative, but also has persistence and high dedication to the business sector that is worked on, confident and able to calculate risk, patience and creative in solving various problems faced. In addition, entrepreneur managers must be able to serve the needs of business activities and help sell the production they produce.

Marver and Slatter (1998: 13) in their research concluded that in order to be competitive in the market, entrepreneurial managers must carry out 3 activities namely consumer orientation, competitor orientation and coordination between functions. Market orientation implemented by cooperatives so that in the market competition the price of goods / services can be maintained in such a way by keeping in mind the movements of competitors, and even controlling the price of goods / services. Partially the participation of members has a positive and significant effect on the implementation of marketing strategies by 0.5192 , meaning that variations in the implementation of marketing strategies are partially 51.92 percent determined by variations in member participation. This proves that member participation is an important factor in determining the implementation of marketing strategies. These findings are consistent with Hanel's (2005: 133) opinion that efficient service improvement through the provision of goods and services by cooperative companies will be an important incentive for members to contribute to the formation and growth of cooperatives. In this case the intensity of stimuli desired by the members is very closely related to how far the goods and services meet the needs that are subjectively felt by each member, so as to increase the interests of the household, farming business or other business units on the influence of entrepreneurial attitudes managers, and member participation on cooperative business performance. Simultaneously, the magnitude of the influence of manager entrepreneurship attitudes and member participation on cooperative business performance is $\mathbf{8 5 . 5 6} \%$, while the remaining $14.46 \%$ is caused by other factors not examined, which are thought to be from internal factors, namely management, external factors namely the role of government and cooperative catalyst parties. 
These findings indicate that the manager's entrepreneurial attitude, and member participation are important factors in determining the level of cooperative performance in East Java Province. Relatively high influence of these two variables simultaneously on cooperative business performance, because the manager's entrepreneurial attitude variable, and member participation is factors inherent to human individuals that are closely related to the formation of cooperative business performance as indicated by the value of statistical correlations between these variables.

\section{Effect of Capital Resources Access to Cooperative Performance.}

Capital is a very important factor in the world of cooperatives, when cooperatives are established, the factors that are first needed are members, second place is capital, without these two factors cooperatives may not be established.

A study on: Study of Antecedent Factors that Influence the Development of Cooperatives and SMEs in North Sumatra is a factor of access to Capital, Technology and equipment, managers and labor (HR), The role of government, market opportunities. http://www.smecda.com/kajian/files/jurnal/ Pg-124.pdf, 6-5-2014

The most dominant main factor faced by small businesses and cooperatives is capital, marketing and the role of government. Given the state of this small business is growing and developing (www.infobisnis.com/jurnal.Pdf).

Access to cooperative finance as part of the management of cooperatives is capital. Next about the source of cooperative capital: As with other forms of business entity, to run its business activities cooperatives require capital, both money and goods. According to article 41 of Law No.25 / 1992 cooperative capital consists of own capital and loan capital.

1). Access to own capital includes the following sources of capital:

a. Basic Savings: Principal savings are money that must be paid by cooperative members when registering as a member

b. Mandatory Deposits, Mandatory deposits are deposits that must be paid by members each month in the same amount.

c. Special Deposits are Voluntary Deposits such as Sacrifice Savings, Deaths, Time Deposits etc.

d. Cooperative Reserve Funds if needed.

e. Grant, is a sum of money or capital goods received from other parties and is not binding.

f. According to the Shari'ah Pattern there is still capital that can be accessed namely: Waqf, Infaq, shodaqoh, zakat maal and productive endowments. (Fiqh Mu'amalat)

2). Cooperative loan capital, from government / bank budgets, from members, bond issuance, productive time etc.: Furthermore, Neti Budiwati (2009) gave a description of the Cooperative Capital as follows: the management's duties as stated in Paragraph 1 Article 30 of Law No. 25 of 1992, among others:

a) Manage and develop cooperatives and all their businesses.

b) Submitting a work plan and Cooperative revenue and expenditure budget.

c) Submit financial reports and the reliability of the implementation of the task.

d) Organize financial responsibility and inventory in an orderly manner. 
The four management tasks above, 3 of them are related to capital management

3). Definition and function of managing cooperative financial capital: What is meant by the management of financial capital is the most profitable commercial activities and designing activities for the use of funds in an efficient and productive manner in line with economic principles and Cooperative principles. The term cooperative financial management above contains several things, including:

a) Management functions, including design, organization, implementation and control functions, and supervision.

b) Activities to access capital, to strengthen activities to get money or capital, both from inside and outside the cooperative.

4). Funds use activities, are activities to invest capital either in the form of labor capital or the progress of permanent activities.

5). The economic principle, is a principle that is used as a principle in various commercial activities consisting of rationality, that is an action that is full of economic calculations in accordance with the objectives of the cooperative:

a. Skill, which is a skill to use economic resources.

b. Messaging / accuracy, which is an achievement of targets from the output or goals to be achieved.

c. Productivity, which is an achievement of expenditure parallel to the input used.

6). The principle of cooperatives and other regulations, namely a main rule that applies in cooperatives as explained previously and the rules that apply to each cooperative. The understanding of cooperative financial management as above illustrates that capital is needed in cooperatives. Although it is said that cooperatives are not a capital association but an association of people, it cannot be denied that capital access is the main factor that can be operated in the welfare of members.

Therefore, access to capital in cooperatives is an important factor and needs to be controlled using financial management principles. Related to capital problems, it is the responsibility of the management to be able to access capital and use it as efficiently and effectively as possible. Optimizing the use of funds is a way to achieve financial management goals in cooperatives. Optimizing the use of capital will be able to maximize profit or SHU and so on will be able to maximize the welfare of members. If SHU increases, members' welfare will also increase. This situation adds to the investor's confidence in the cooperative. With this trust, cooperatives have the opportunity and are believed to develop even greater capital (Budiwati Neti, 2009). Neti also reminded, that in relation to cooperative activities, financial expenditure management is a basic function that must receive serious attention. In this case, the management or manager of the cooperative must have a goal to:

a. Realizing stability over capital management and good solvency.

b. Realizing optimum utilization of capital.

c. Realizing effort to form their own capital.

The three things above are some of the indicators of financial achievement and cooperative efforts. The success of the cooperative management manifests all three, it means that the management has achieved good financial achievements.

\section{Variable Effects of Cooperative Performance with Member Economics.}

Cooperative Performance Theory. Performance is the achievement achieved by the company / cooperative in a certain period that reflects the level of health of the company / cooperative. According to Mwita (2000) defining performance as an outcome of a job, because it provides a 
strong relationship with the company's strategic goals. While Hyndman and Anderson (1997) states that performance can be seen as a production model consisting of 3 stages: input, process and output / result, so that performance can be interpreted as the efficiency and effectiveness of a company's desires or programs, such as development programs products, marketing programs, HR development programs, mergers and acquisitions programs and customer costomization programs, and others. From some of these companies it can be concluded that performance is the effectiveness and efficiency of company programs and can make an economic contribution to the company. Basically, performance can be grouped into two types, namely financial and non-financial performance, or quantitative performance, and qualitative performance (Dawam Rahajo, 1997: 82) This measure of financial performance is also often used by many researchers in assessing cooperative performance, that is, it does not differentiate from private performance, which consists of Return on equity (ROE), Dept to equity (DTE) and operating earnings to the interest (OETI) between cooperative companies and with other private companies is the same / no different, Lerman and Paliamen (1990). The most widely used measure to measure the performance of a company (in terms of profit) is ROI (Return On Investments), which is simply the profit sharing before tax with total assets of Wheelen and Hunger, (2005). Other provit measurement tools are EPS (Earnings per Share) and ROE (Return of Equite). But unfortunately these two measuring tools have weaknesses because they are derived from accounting basic data such as EPS. Besides that it can not be related to the stock price of a company. Therefore the last two measuring tools are inadequate to measure the performance of companies / cooperatives. Understanding ROI (Wheelen and Hunger, (2005) above is in principle the same as productivity, but in general ROI refers to value while productivity refers to quantity (Quantity). This can be seen from the definition of productivity by Rollison et al (1998; 40) define productivity as the amount of output obtained from a number of specific inputs. Next explained that productivity is a measure of efficiency which is the ratio between output and input. This means that the greater the ratio the more efficient use of inputs from a business. So business productivity is the ratio between the results of operations obtained (Output) with the amount of resources used (input)

Thus the performance of a company can be seen from the results achieved as a whole, such as sales results before and after the company's productivity tax and labor as an important input to the production process. According to Robbins (207: 121) performance is the optimal achievement in accordance with the potential possessed by an employee is something that always concerns the leaders of the organization. This performance illustrates the extent of one's activities in carrying out tasks and trying to achieve the goals set.

\section{The Variable Effect of Member Economy on Welfare, Some Meanings:}

1. Member economics (Cooperative) is any business that organizes the utilization and utilization of economic resources of its members on the basis of cooperative principles and rules of economic business to meet the needs of life and improve the living standards of members in particular and the work area community in general (Tutik Arniati , 2013)

2. Cooperative economy, is a family-based joint organization that aims to find profit or profit both for the members themselves and also for the general public around them. Cooperative economy is a business organization that is operated jointly based on the principle of the people's economic movement based on kinship, aims to achieve economic interests to improve mutual prosperity both for all members of the cooperative itself and for the surrounding communities who need it. 
3. Cooperative Entrepreneurship, is a positive mental attitude in trying to cooperate cooperatively, by taking innovative initiatives as well as the courage to take risks and hold fast to the principles of cooperative identity, in realizing the fulfillment of real needs and increasing mutual prosperity. From this definition, it can be stated that cooperative entrepreneurship is a positive mental attitude in trying cooperatively. The main task of cooperative entrepreneurs is to take innovative initiatives, which means trying to find, find, and take advantage of opportunities that exist for the common good.

4 TheoryTheory of Member Welfare, Level of satisfaction and welfare of members are two interrelated notions. The level of satisfaction refers to the state of the individual or group, while the level of welfare refers to the state of the community or the wider community. Well-being is an aggregate condition of individual satisfaction. Prosperous understanding of the English word: peaceful and prosperous; tranquil; calm and undisturbed; and safe means peace and prosperity; quiet; calm and undisturbed; safe, with the fulfillment of basic needs of life so that they feel safe and calm.

5. Social Welfare According to Law No. 11 of 2009, is a condition

The fulfillment of citizens' material, spiritual and social needs in order to be able to live properly and be able to develop themselves, so that they can carry out their social functions. The problem of social welfare that is developing today shows that there are citizens who have not fulfilled their basic rights properly because they have not yet received social services from the state. The main task of a cooperative business entity is to support the economic interests of its members in order to advance the welfare of members (promotion of the member's welfare). If there is an excess ability of cooperative services to its members, the excess capability of the service can be used to meet the needs of the community / participants who are non-cooperative members. According to Drewnoski (1974) in Bintarto (1989), looking at the concept of welfare from three aspects; (1) by looking at the level of physical development (somatic status), such as nutrition, health, life expectancy, and part of it; (2) by looking at his mental level, (mental / educational status) such as education, work, and so on; (3) by looking at integration and social status (social status).

\section{HYPOTHESIS}

Based on the formulation of the problem, research objectives, literature review, thinking framework and conceptual framework that has been explained previously, the research hypothesis can be arranged as follows:

1. Government Support has a significant effect on the performance of cooperatives in Batu City, East Java Province.

2. The participation of members of the Cooperative has a significant effect on the performance of the Cooperative in Batu City, East Java Province.

3. The performance of Cooperative Managers has a significant effect on the performance of cooperatives in Batu City, East Java Province.

4. Access to Capital Resources has a significant effect on the performance of cooperatives in Batu City, East Java Province.

5. The performance of cooperatives has a significant effect on the economy of members of cooperatives in Batu City, East Java Province.

6. The performance of cooperatives has a significant effect on the welfare of cooperatives in Batu City, East Java Province.

7. Member economics significantly influence the welfare of cooperatives in Batu City, East Java Province. 


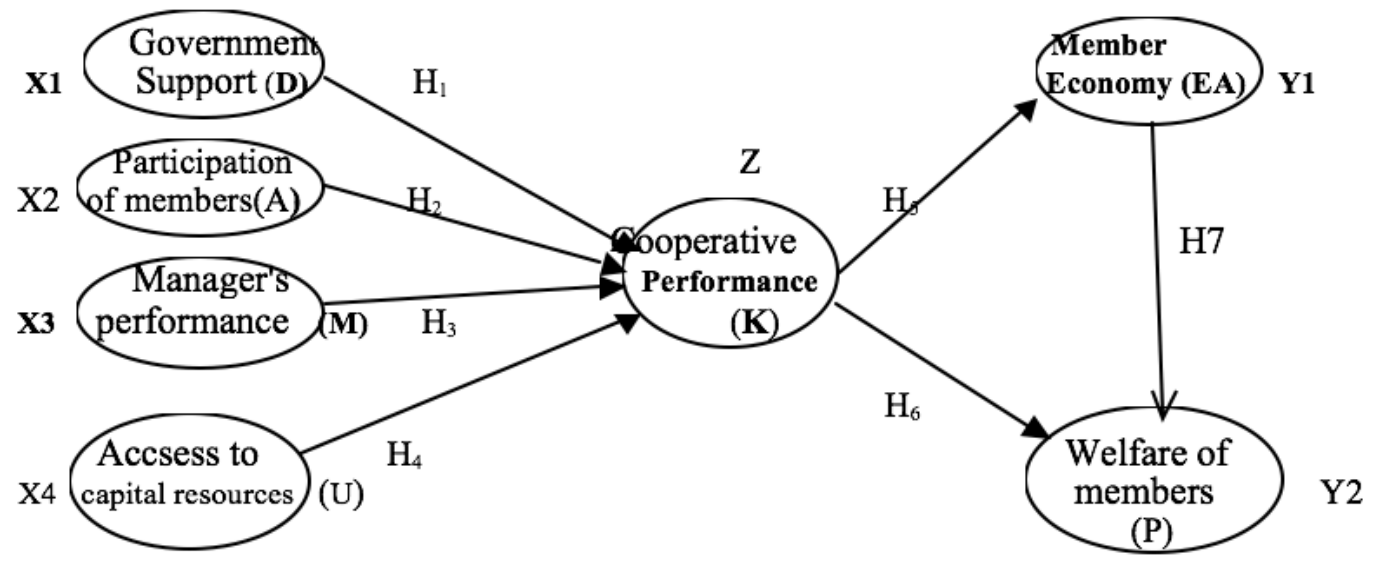

Figure 1. Framework for Concepts of Thought

\section{RESEARCH METHODE}

This research is an explanatory study through hypothesis testing. By using 2 versions of analysis tools, namely Regression Analysis and AMOS Analysis (with SEM / Structural Equation Modeling analysis). Amos is needed to find out more in detail about the various factors / variables and find the indicator that has the most dominant estimation influencing the progress of the cooperative.

\section{ANALYSIS AND DISCUSSION}

Based on structural analysis decision equation modeling (equation model) shows that the criteria of goodness of fit produced most of them already meet the requirements as a table like the following:

Table: 1 Decision Goodness - of - Fit

\begin{tabular}{|l|c|c|c|}
\hline \multicolumn{1}{|c|}{ Goodness of Fit-Indeks } & Cut-off Value & $\begin{array}{c}\text { Hasil Good-ness } \\
\text { offit }\end{array}$ & Information \\
\hline $\mathrm{X}^{2}$ - Chi-square & Expected to be small & 809.815 & Good \\
\hline Sig. Probbability & $\geq 0.05$ & 0.78 & Good \\
\hline CMIN atau DF & $<2.00$ & 1.074 & Good \\
\hline RMSEA & $\leq 0.08$ & 0.018 & Good \\
\hline GFI & $\geq 0.90$ & 0.959 & Good \\
\hline AGFI & $\geq 0.90$ & 0.931 & Good \\
\hline
\end{tabular}

Test "Regression Weight" Decision analysis (equation model / SEM) using the help of the amos 18 program

Table : 2

Decision Analysis of Regression Weight

From the research results of the Hypoyesis Test

\begin{tabular}{|c|c|c|c|c|c|c|c|c|}
\hline & & & & Esitame & SE & CR & P & SIGN \\
\hline H1 & $\mathrm{P}$ & $\leftarrow$ & $\mathrm{D}$ & 902 &, 425 & 3,123 &, 034 & Sign \\
\hline $\mathrm{H} 2$ & $\mathrm{P}$ & $\leftarrow$ & $\mathrm{A}$ & 510 &, 259 & 1,969 &, 049 & Sign \\
\hline $\mathrm{H} 3$ & $\mathrm{P}$ & $\leftarrow$ & $\mathrm{M}$ & 390 &, 125 & 3,724 &, 046 & Sign \\
\hline $\mathrm{H} 4$ & $\mathrm{P}$ & $\leftarrow$ & $\mathrm{U}$ & 352 &, 168 & 2,092 &, 036 & Sign \\
\hline $\mathrm{H} 5$ & $\mathrm{P}$ & $\leftarrow$ & $\mathrm{K}$ & 833 &, 547 & 1,973 &, 028 & Sign \\
\hline H6 & $\mathrm{P}$ & $\leftarrow$ & $\mathrm{EA}$ & 113 &, 172 & 6,571 &, 011 & Sign \\
\hline H7 & $\mathrm{P}$ & $\leftarrow$ & $\mathrm{P}$ & & & & & Sign \\
\hline
\end{tabular}




\section{Explanation:}

Based on Table 2 above shows all the variables have a significant influence on the performance of cooperatives in the Tourism City of Batu, East Java Indonesia, namely Government Support (D) with a significant value of 0.034; Urban Participation (A) with a significant value of 0.049; Manager performance (M) with a significant value of 0.046; Capital Access (U) with a significant value of 0.036; Cooperative Performance $(\mathrm{K})$ with a significant value of 0.028 ; and Member Economics (EA) with a significant value of 0.011 . And the most dominant estimation influencing the progress of the cooperative. On Government Support with a value of 902, on the performance of cooperatives with a value of 833 , and on the participation of members with a value of 510 .

The decision of the analysis shows that all research hypotheses are proven correct

\section{CONCLUSION}

From the results of the analysis and discussion above, it can be concluded as follows:

1. Background of Respondents

That based on the descriptive statistical analysis in Table 5.8 above it can be concluded that a summary of the overall percentage of respondents according to demographics there are 7 variables namely gender, age, marriage, type of work, education, position, and profit, which influence there are real differences. The results of the T-Test for work, age and education and work experience in cooperatives have a significantly greater value than 0.050, which shows that according to the demographics of cooperative management respondents have a similarity/influence the relationship on cooperative performance and member welfare, at least support the hypothesis.

There are three more respondent background variables that have a significant value or no influence on the cooperative's performance relationship in the Tourism City of Batu, East Java, Indonesia. These variables are: Gender, marital status, and profit while being administrators.

2. That based on the results of the 6 veriabel unidimensionality test of Government Support, member participation, manager performance, access to capital resources, cooperative performance, member economics and member welfare with its indicators using the CFA. The average is stated as good, (from tables 5.16. - 5.22)

3. Based on the results of the Analysis Decision (Regression Weight) Test the model in table 5.41 to table 5.49 that 7 hypotheses that have been tested are proven to have a significant effect, namely:

a. Government Support has proven to have a significant effect on the performance of cooperatives in Batu City, East Java Province.

b. The participation of members of the Cooperative also proved to have a significant effect on the performance of the Cooperative in Batu City, East Java Province.

c. The performance of the Cooperative Manager is proven to have a significant effect on the performance of the Cooperative in Batu City, East Java Province.

d. Access to Capital Resources proved to have a significant effect on the performance of cooperatives in Batu City, East Java Province.

e. The performance of cooperatives proved to have a significant effect on the economy of members of cooperatives in Batu City, East Java Province.

f. Cooperative Performance It is also proven to have a significant effect on the welfare of the Cooperative.

g. Members' economy is also proven to have a significant effect on increasing the welfare of cooperative members in Batu City, East Java Province. 
All of them have been proven to have a significant significant effect on the performance of cooperatives and the welfare of members. Thus it has answered all research hypotheses and research problems as outlined in the discussion. With the entire hypothesis test proven to be true, the results of the hypothesis test at the same time a nswer all research problems.

4. The largest estimate of each variable $=$ each of these factors based on the Loading Factor Analysis Decision are:

a. The Government Support Variable is indicator D4 (Strengthening capital), with an Estimated value of 2,246 and a value of $\mathrm{P}={ }^{* * *}<$ of 0.05 .

b. In the Member Participation Variable is the A4 indicator (Member who is creative and resilient) with an estimated value of 1,414 and a value of $\mathrm{P}=$. $^{* * *}<$ of 0.05

c. The Manager Performance Variable is indicator M5 (has 16 entrepreneurial characters) with an estimated value of 9,483 and a P value of $.35<0.05$

d. In Capital Source Access Variable is indicator U1 (adequate capital / a minimum of Rp.200 million), with an Estimated value of 1,215 and a value of $\mathrm{P}=.^{* * *}<$ of 0.05 .

e. The Cooperative Performance Variable is the K4 indicator (Professional Staff), with an Estimated value of 1,750 and a P value $={ }^{* * *}<$ of 0.05 .

f. In the Member Economic Variable is the indicator EA4 (increased Member Welfare), with an Estimated value of 1,961 and a value of $\mathrm{P}={ }^{* * *}<0$ of 0.05 .

g. The Member Welfare Variable is indicator P4 (achieved Member welfare), with an Estimated value of 0.902 and a $P$ value $=.34<$ of 0.05 .

\section{LIMITATION}

In this research process, it has been tried as optimal as possible, but on the other hand there are still weaknesses and limitations faced, including:

1. The object of this research is carried out in a cooperative movement that is very diverse, both the organization, its business, the background of the management and its members, its market, and the location of the region, and its diverse types and qualifications, so in determining the sample it is necessary to examine more closely so as not to choose the wrong choice, but faced with lack of disclosure of information for selected qualifications,

2. It may be understood that not all of the several analytical tools are mastered, so they must first study deeper or use experts in their fields even though their position is only as a tool (analysis), but if they do not master themselves, it is felt to be less convincing. The author realizes that no human work is perfect except God, but it must be done as well as possible. In addition, it is undeniable that there are still some limitations that are thought to have a slight effect on research results.

3. Batu City as a tourist city that has a style and special characteristics that are not the same as other cities, and most locations are characterized by agriculture and plantations, although the goal is the same, namely how the welfare of members and surrounding communities. but the research objective is to examine the effect of the relationship between variables that influence the progress of cooperatives in order to improve the performance of cooperatives, so that the economy will rise and the community will prosper.

4. This research was conducted using a mixed method, namely by field surveillance, also through quesionare, input list of cooperative practitioners respondents, if necessary interviews so that researchers can gain more knowledge as a supporting science in the study by directly involved in some of the respondents' activities. But decision making 
remains based on the results of the analysis with the analysis tools used because it must be accounted for scientifically.

\section{BIBLIOGRAPHY}

Arifin B., (1996a) Kapita Slecta Manajemen \& Bisnis, FE Press.

Budiwati Neti (2009), Manajemen keuangan dan permodalan, diperoleh Jun,7-2014 dari http://netibudiwati.com/ 2009/03/manajemen-keuangan-dan-permodalan. html.

Craven (2006), Efek Timbal Balik Konsep Diri dan Kinerja Dari Perspektif Multidimensi: Melampaui Kesenangan yang Menggoda dan Perspektif Unidimensional, Artikel Penelitian. https://doi.org/10.1111/j.1745-6916.2006. $\underline{00010 . x}$

Davis Peter, (2003) Co-Operative Identity and Co-Operatif Management, ICA. Departemen

Dawam Rahardjo, (2009) Wawasan dan visi pembangunan abad 21 Indonesia, Jakarta, Intermasa,

Drewnowski, J. (1974). On Measuring and Planning the Quality of Life. The Hague Mouton.

Hair et al, (2010) Scholarly articles for sample size, Cortisol levels in hair of East Greenland polar bears - Bechshøft Cited by 79

Hanel, Alfred. 2005. Organisasi Koperasi. Pokok-Pokok Pikiran Mengenai Organisasi Koperasi dan Kebijakan Pengembangannya di Negara-Negara Berkembang. Yogyakarta : Graha Ilmu.

-(2006a). Organisasi koperasi.Bandung. Universitas Padjadjaran. Diperoleh Jun,7 2014 dalam Rozi dan Hendri. 1997. Dari http://educare.e-fkipunla.net/index2.php? option=com_content\&do_pdf.

Hyndman and Anderson( 1997) Financial \& Acountabity Management In Govenrments, Public Services Dan Carrities

Lukman M. Baga (2003), Koperasi dan Kelembagaan Agribisnis, Departemen Agribisnis Fakultas Ekonomi Manajemen, Institut Pertanian Bogor ...

Marver dan Slatter (1998) Dipimpin oleh Pelanggan dan Berorientasi Pasar: Jangan Membingungkan Keduanya, Departemen Pemasaran \& Bisnis Internasional, Univ. Washington Seattle

Melcher (1994) Basic and Applied Memory Research: Volume 1: Theory in Context; Vol. 2

Mueller (1996:9), Sumber Daya Manusia Sebagai Aset Strategis: Teori Berbasis Sumber Daya Evolusioner * Journal of Management studies

Mwita (2000) Model manajemen kinerja: Pendekatan berbasis sistem untuk kualitas layanan publik, Departemen Pengembangan Internasional, Universitas Birmingham, Birmingham, UK)

Noor Akhlan D (2010), Partisipasi Anggota Koperasi, diperoleh April 10-2014 dari WWW.simple artist. com.

Pratiwi K, (2010), Perilaku Prososial ditinjau dari Empati dan Kematangan Emosi. Jurnal Psikologi, Volume I, No 1. Kudus: Universitas Muria Kudus.

Robbins (2001:187) Robbins, Stephen P. 2001. Perilaku Organisasi: Konsep, Kontroversi, Aplikasi, Jilid 1, Edisi 8, Prenhallindo, Jakarta.

---------, (2001) Peran Kepemimpinan dalam Pengelolaan Koperasi, Prenhallindo, Jakarta.

Rollison et al (1998) Motivation and Leadership, a wider perspective, textbook, 2nd edition, pg 12-22, Macmillan Publication limited.Taylor, K.F. (1974) Valence-Expectancy Approach to Work Motivation and Personnel, Journal of College Management, London school of business, vol 4 pg 43-53, London Press.

Ropke.(1995). Manajemen Strategi Untuk Koperasi dan Organisasi. Swadaya Bandung. IKOPIN.

Ropke, J. 2003. Ekonomi Koperasi Teori dan Manajemen. Terjemahan Sri Djatnika. Jakarta : Salemba Emp

Sekaran, Uma (2010) Research Methods For Business A Skill-Building Approach,John Wiley \&Sons Ins, New York Chichester Brisbane Totronto Singapore. 